\title{
Current views on the function of the lymphatic vasculature in health and disease
}

\author{
Yingdi Wang and Guillermo Oliver ${ }^{1}$ \\ Department of Genetics and Tumor Cell Biology, St. Jude Children's Research Hospital, Memphis, Tennessee 38105, USA
}

The lymphatic vascular system is essential for lipid absorption, fluid homeostasis, and immune surveillance. Until recently, lymphatic vessel dysfunction had been associated with symptomatic pathologic conditions such as lymphedema. Work in the last few years had led to a better understanding of the functional roles of this vascular system in health and disease. Furthermore, recent work has also unraveled additional functional roles of the lymphatic vasculature in fat metabolism, obesity, inflammation, and the regulation of salt storage in hypertension. In this review, we summarize the functional roles of the lymphatic vasculature in health and disease.

In mammals, two specialized vascular systems are responsible for effective circulation: the blood vasculature, which delivers oxygen and nutrients, and the lymphatic vasculature, which transports fluid and macromolecules from tissues back to the blood circulation. These two highly branched endothelial tubular networks are closely related. In mammals, lymphatic vessels originate from embryonic veins and form an independent, unidirectional vascular system that interconnects with blood vessels at a few specific sites (Karpanen and Alitalo 2008). The appropriate function of blood vessels is crucial for the delivery of oxygen and nutrients and carries away waste products for detoxification and replenishment. The lymphatic vasculature, however, plays important roles in immune surveillance, lipid absorption, and maintenance of tissue fluid balance (Harvey and Oliver 2004; Oliver and Alitalo 2005; Tammela and Alitalo 2010).

The lymphatic system is also crucial during the immune response to infectious agents because afferent lymphatic vessels are the route through which dendritic cells migrate to the lymph nodes and lymphoid organs after antigen uptake. Dendritic cells, macrophages, and memory $\mathrm{T}$ lymphocytes use the lymphatic network to move from peripheral tissues to regional lymph nodes. In most forms of cancer, metastastatic spreading of tumor cells occurs

[Keywords: Lymphangiogenesis; lymphatic vasculature; inflammation; obesity; tumors; metabolism; Prox1]

${ }^{1}$ Corresponding author.

E-MAIL guillermo.oliver@stjude.org; FAX (901) 595-6035.

Article is online at http://www.genesdev.org/cgi/doi/10.1101/gad.1955910. through the lymphatic vascular network. Although few life-threatening diseases result from malfunction of the lymphatic vasculature, failure of lymph transport promotes lymphedema, a disfiguring, disabling, and occasionally lifethreatening disorder.

In the last few years, a number of genes regulating different aspects of developmental and postnatal lymphangiogenesis have been identified /Oliver and Srinivasan 2008) and valuable animal models have become available. These tools have not only helped us to improve our understanding of different lymphatic-related pathologic conditions and their relationship with inflammation, autoimmunity, and cancer, but also to re-evaluate the functional roles of the lymphatic vascular network. For example, lymphatic vascular defects were identified as leading causes of late-onset obesity in a mouse model (Harvey et al. 2005), and subcutaneous lymphatic vessels participate in regulating blood pressure after excessive salt intake (Machnik et al. 2009).

In this review, we focus on some of the recent progress in the field of lymphatic vasculature malfunction and diseases.

\section{Lymphatic vasculature}

During embryonic development, the blood vasculature is generated through two distinct processes known as vasculogenesis and angiogenesis (Risau and Flamme 1995; Flamme et al. 1997). Vasculogenesis is the de novo assembly of vessels by endothelial precursor cells, so-called angioblasts, and angiogenesis involves the growth and remodeling of pre-existing blood vessels into a more complex and elaborated vascular network (Adams and Alitalo 2007). The development of the lymphatic vasculature is secondary to that of blood vessels. Using a detailed lineage tracing approach, Srinivasan et al. (2007) have recently confirmed the proposal made by Sabin (1902) more than a century ago postulating that the lymphatic vasculature originates from the embryonic veins.

The lymphatic vascular network develops in a stepwise manner (Oliver and Detmar 2002; Wigle et al. 2002; Oliver 2004). In the mouse, this process starts at approximately embryonic day 9.75 (E9.75) in the anterior cardinal vein (Srinivasan et al. 2007). Some of the key players controlling 
the necessary steps in this process have been identified in the last decade (Oliver 2004; Harvey and Oliver 2004; Oliver and Alitalo 2005; Adams and Alitalo 2007).

The lymphatic vascular network consists of smaller blind-ended capillaries and larger collecting lymphatic vessels (Fig. 1). The lymphatic capillaries are composed of a single layer of overlapping endothelial cells (ECs) and lack a continuous basement membrane and pericytes (i.e., the smooth muscle-like contractile cells that wrap around the outer surface of blood vessels) (Fig. 1). Therefore, the lymphatic capillaries are highly permeable to interstitial fluid and macromolecules, such that, when the surrounding interstitial pressure changes, these lymphatics either expand and fill with lymph or contract and push lymph (Leak and Burke 1966). These lymphatic capillaries first drain into precollecting lymphatic vessels, which will eventually merge into larger secondary collecting lymphatic vessels covered by smooth muscle cells that provide contractile activity to assist lymph flow and possess a continuous basement membrane. Tissue fluid collected in the larger collecting lymphatics drains into the thoracic duct and is then returned to the blood circulation through lymphatic-vasculature connections at the junction of the jugular and subclavian veins.

\section{Lymphatic vasculature malfunction and disease}

\section{Lymphedema}

Malfunction of the lymphatic vasculature can result in congenital or acquired disorders such as lymphedema (i.e., imbalance in lymph absorption), which is a disfiguring and disabling disorder often characterized by swelling of the extremities, tissue fibrosis, accumulation of subcutaneous fat, and susceptibility to infections (Fig. 2; Rockson 2001; Witte et al. 2001; Johnson and Oliver 2009). Primary lymphedema has a genetic origin and secondary lymphedema arises as the result of surgery, infection (e.g., filiariasis), or radiation therapy (Rockson 2001; Witte et al. 2001). Primary lymphedema can be present at birth in the form of Milroy disease, an inherited form of primary lymphedema characterized by the absence or reduction in the number of lymphatic vessels (Milroy 1892), or appear after birth, mainly around puberty (Meige disease) (Meige 1898). In general, both of these diseases are characterized by dilated lymphatic vessels and accumulation of lymph fluid.

The typical accumulation of interstitial fluid observed in lymphedema results from insufficient lymph transport or occlusion of lymphatic drainage caused by hypoplasia or damage of the lymphatic vessels, impaired lymphatic function, or obstruction of lymph flow (Fig. 2; Witte et al. 2001). Although lymphedema is rarely a life-threatening condition, it severely affects the quality of life of affected individuals, and effective treatment is unavailable.

Primary lymphedema Specific genetic defects have been identified recently in hereditary diseases associated with primary lymphedema. For example, heterozygous missense mutations in vascular endothelial growth factor receptor 3 (VEGFR3) have been identified in several cases of Milroy disease (Ferrell et al. 1998; Irrthum et al. 2000; Karkkainen et al. 2000). Mutations in this gene are also responsible for the mutant mouse strain Chy, which has defective lymphatic vessels and develops chylous ascites and lymphedematous limb swelling after birth (Karkkainen et al. 2001). This animal model has been used to test targeted gene therapy and adenoviral expression of VEGF-C (one of the ligands of VEGFR3) (Joukov et al. 1996, 1997; Achen et al. 1998), which promotes the formation of functional lymphatic vessels in these mice (Karkkainen et al. 2001). Functional inactivation of Vegfc in mice revealed that this gene's activity is essential for the budding and proliferation of lymphatic ECs (LECs) that are located in the embryonic veins and express Prox1, a transcription factor essential for specifying the LEC phenotype and forming the entire lymphatic vasculature network (Karkkainen et al. 2004; Wigle et al. 2002). However, Vegfc heterozygous mice survive to adulthood, but exhibit cutaneous lymphatic hypoplasia and lymphedema (Karkkainen et al. 2004).

Similarly, mutations in the forkhead transcription factor FOXC2 have been identified in patients with lymphedema-ditichiasis (LD) syndrome (Fang et al. 2000; Finegold et al. 2001). This autosomal dominant disorder is characterized by distichiasis (i.e., a double row of eyelashes) at birth and bilateral lower limb lymphedema at puberty (Neel and Schull 1954; Falls and Kertesz 1964).
Blood vasculature

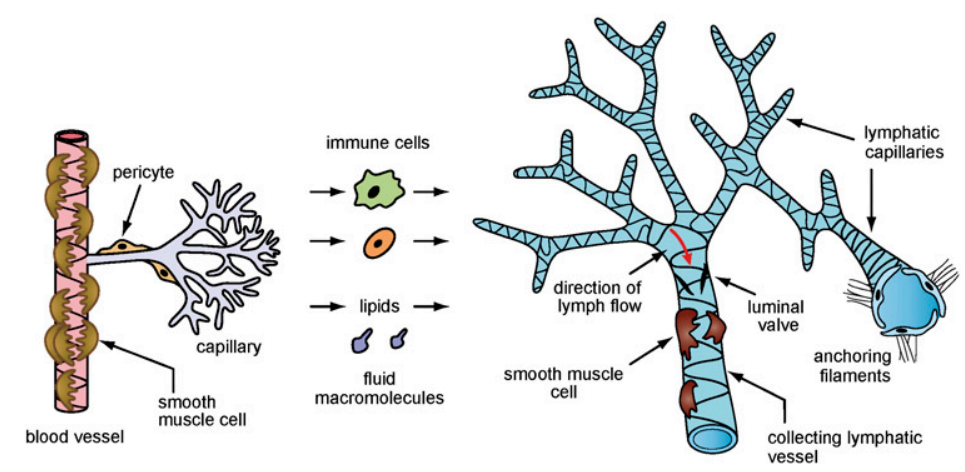

Figure 1. The lymphatic vascular network includes blind-ended capillaries and larger collecting lymphatic vessels. The lymphatic capillaries are composed of a single layer of overlapping ECs and lack a continuous basement membrane. Collecting lymphatic vessels are covered by smooth muscle cells, and possess a basement membrane and luminal valves that prevent lymph backflow. The unique structure of capillary lymphatic vessels allows for the uptake of interstitial fluid, macromolecules, cells, and lipids that filtrate continuously from the blood capillary network. 


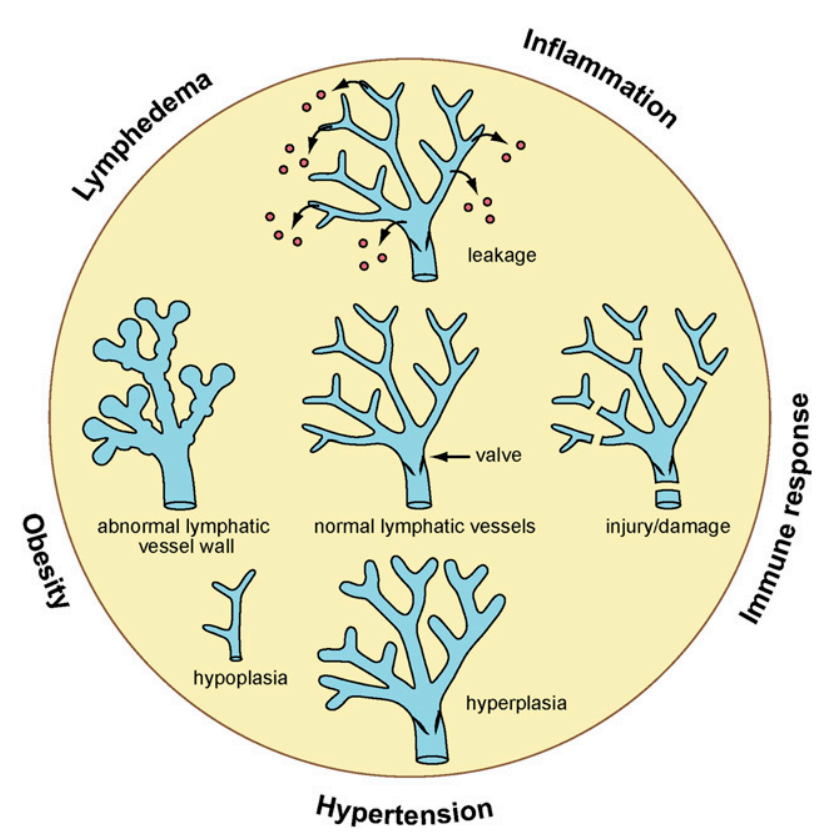

Figure 2. Different types of alterations in the lymphatic vascular network can lead to a variety of pathological conditions or impact the inflammatory or immune responses. Hypoplastic, hyperplastic, mispatterned, or damaged (e.g., mechanical) lymphatics can result in different types of primary or secondary lymphedema. Meanwhile, leaky lymphatics can promote obesity.

Unlike congenital lymphedema, the number of lymphatic vessels appears to be normal in individuals with LD; however, these patients have impaired lymphatic drainage (Brice et al. 2002). This alteration could be due to the abnormal mural cell coating of the lymphatic capillaries and the lack of luminal valves in the collecting lymphatics that has been identified in patients with LD and in Foxc2 mutant mice (Fig. 2; Petrova et al. 2004).

Mutations in the transcription factor SOX18 were identified in recessive and dominant forms of hypotrichosis-lymphedema-telangiectasia (HLTS), a rare disease characterized by the absence of eyebrows and eyelashes, edema of the inferior members or eyelids, and peripheral vein anomalies (Irrthum et al. 2003). In mice, depending on the genetic background, the functional inactivation of Sox18 results in embryonic lethality, and the mutant embryos exhibit edema and lack a lymphatic vasculature (Francois et al. 2008). Sox18 was reported to act as an upstream regulator of Proxl expression in the embryonic anterior cardinal vein (Francois et al. 2008). The Ragged mouse, which has a spontaneous point mutation in Sox18, is considered to be a likely model for HLTS. These mice exhibit defective vasculogenesis and folliculogenesis as well as malformation of lymphatic vessels, which are similar to those of humans with HLTS (Pennisi et al. 2000; Irrthum et al. 2003; Francois et al. 2008).

Another gene affected in primary lymphedema is integrin- $\alpha 9$ (ITGA9): Mutations in this gene have been reported recently in fetuses with congenital chylothorax (Ma et al. 2008). Similar to humans with this condition, Itga9-null mice exhibit chylothorax and die a few days after birth (Huang et al. 2000), and the characterization of recently generated Itga9-conditional mutant embryos has revealed that ITGA9 is required for proper lymphatic valve morphogenesis (Bazigou et al. 2009).

Hennekam syndrome is a rare, heritable disease characterized by lymphedema, lymphangiectasia, and developmental delay; the lymphedema usually becomes apparent in the face and limbs at birth or in early infancy (Van Balkom et al. 2002). Mutations in collagen and calciumbinding EGF domain-1 (CCBE1) are responsible for this disease (Alders et al. 2009), and ccbe1 is required for embryonic lymphangiogenesis and lymphatic sprouting from the venous endothelium in zebrafish (Hogan et al. 2009). Unexpectedly, mutations in RELN, a gene thought to function only in the brain, have also lead to congenital lymphedema in at least three patients with persistent neonatal lymphedema, and in one with accumulation of chyle (Hong et al. 2000).

Finally, although the chromosomal locations for Turner syndrome (whose patients exhibit lymphedema) and cholestasis-lymphedema (i.e., Aagenaes syndrome) have been mapped to Xp11.2-p22.1 and 15q, respectively, the identity of the genes involved in these disorders remains unknown (Zinn et al. 1998; Bull et al. 2000).

Secondary lymphedema Worldwide, most cases of lymphedema are secondary and due to some type of damage to the lymphatic vasculature. Among the causes of this damage, filariasis (i.e., elephantiasis) is the most common one, affecting $>100$ million people, mostly in tropical areas (Wynd et al. 2007; Pfarr et al. 2009). Filariasis itself is the result of parasitic infection by mosquito-borne worm parasites that localize to the lymphatic system, where an inflammatory reaction triggers the production of VEGF, VEGF-C, and VEGF-D. Eventually, hyperplasia, obstruction, and extensive damage of the lymphatic vasculature occur (Fig. 2), resulting in chronic lymphedema of the lower limbs or genitalia and permanent disability (Rockson 2001; Pfarr et al. 2009). Treatment with drugs targeting the microfilariae (larval offspring) has been the main approach to treat this disease (Hoerauf et al. 2003). Recently, a novel more efficient approach aimed to directly target the intracellular bacterial symbiont of filarial parasites (Wolbachia) was shown to kill most adult worms without causing severe side effects (Stolk et al. 2005).

In contrast to the abundance of filariasis-promoted lymphedema in tropical areas, the leading cause of secondary lymphedema in the industrialized world is lymph node dissection or radiation therapy that damages the lymphatic vasculature (Fig. 2) after breast cancer surgery (Rockson 2001) and affects $\sim 15 \%-20 \%$ of women undergoing breast cancer treatment (Vignes et al. 2007).

Unfortunately, treatment for lymphedema is still based mainly on conservative therapies such as manual drainage, massage, compression garments, liposuction, and dietary modification (i.e., limiting the consumption of long-chain fatty acids) (Rockson 2001; Brorson 2003). Previous work has shown that VEGF-C can induce capillary lymphatic vessel growth in animal models (Karkkainen et al. 2001; Szuba et al. 2002; Yoon et al. 2003; Saaristo et al. 2004), and 
a recent study in mice demonstrated that treatment with adenovirus-delivered VEGF-C/D promotes the regeneration of functional collecting lymphatic vessels after the excision of axillary lymph nodes and the associated collecting lymphatic vessels (Tammela et al. 2007). Therefore, it appears that VEGF-C/D growth factor therapy combined with lymph node transplantation could become a feasible clinical approach to restore the entire lymphatic network in damaged tissues, particularly in cases of injury or side effects following surgery (Tammela et al. 2007).

\section{Lymphangioleiomyomatosis (LAM)}

LAM is a rare, cystic lung disease that is progressive and often lethal (Kumasaka et al. 2004, 2005; Juvet et al. 2006, 2007; Seyama et al. 2006). LAM is characterized by the proliferation of abnormal smooth muscle-like cells (i.e., LAM cells) that form LAM lesions in the lungs, axial lymph nodes, and other organs. This disease is often associated with renal angiomyolipomas (AMLs) (Kumasaka et al. 2004, 2005; Juvet et al. 2006, 2007; Seyama et al. 2006) and frequently causes chylothorax by obstructing pulmonary lymphatic vessels (Kumasaka et al. 2004; Juvet et al. 2007). LAM primarily affects females of childbearing age and results from mutations in one of the tuberous sclerosis complex (TSC) genes, usually TSC2 (Kumasaka et al. 2005; Karpanen and Alitalo 2008). Interestingly, it has been proposed that LECs play an essential role in LAM lesion dissemination, and that LAM-associated lymphangiogenesis plays a role in LAM progression (Kumasaka et al. 2004, 2005). Recent results have revealed that VEGF-C and VEGF-D induce the proliferation of LAM-derived cells (LDC) via an autocrine cross-talk with LECs (Issaka et al. 2009).

\section{Lymphangiectasia}

Lymphangiectasia (i.e., dilation of the lymphatic vessels) is most often seen in the lung, intestine, and thoracic cavity (Faul et al. 2000). Congenital pulmonary lymphangiectasia is a rare disorder of newborns and is often fatal. Affected individuals exhibit cyanosis and labored breathing, and often have chylothorax or chylous effluence in the thoracic cavity (Bellini et al. 2006). Intestinal lymphangiectasia is characterized by highly dilated lymphatic capillaries in the intestinal villi. Because the normal lymphatic response to changes in interstitial pressure is hindered by this hyperdilation, absorption by the intestine is compromised. Moreover, the levels of FOXC2 and SOX18 transcription are significantly lower in these patients (Hokari et al. 2008; Johnson and Oliver 2009).

\section{Lymphatic vasculature and inflammation}

Inflammation is the normal biological response of vascular tissues to harmful stimuli such as injury, infection, or tumors. Although it is well known that the blood vasculature is an important regulator of the inflammatory process, the role of the lymphatic network in this process is becoming better understood, as several lines of new evi- dence revealed that inflammation triggers lymphangiogenic signals (Cursiefen et al. 2004; Kunstfeld et al. 2004; Baluk et al. 2005, 2009; Maruyama et al. 2005; Kerjaschki et al. 2006; Flister et al. 2010). Additionally, blood and lymphatic vessels undergo extensive remodeling during chronic inflammation (e.g., asthma, pulmonary disease, rheumatoid arthritis, and inflammatory bowel disease).

During inflammation, different chemokine receptors regulate the recruitment of leukocytes and the inflammatory response. Among those, the chemokine receptor D6 acts as a decoy for inflammatory CC chemokines, and mice deficient for this receptor exhibited increased inflammation (Jamieson et al. 2005; Martinez de la Torre et al. 2005). Interestingly, this receptor is expressed on the lymphatic endothelium, where it might influence the inflammatory response (Nibbs et al. 2001).

The lymphatic vasculature regulates inflammatory responses by transporting leukocytes and antigen-presenting cells from the site of inflammation to the lymph nodes and other secondary lymphoid organs. After inflammatory reactions, activated dendritic, T, and B cells capture antigens and migrate through afferent lymphatic vessels into the lymph nodes. At the same time, macrophages and mast cells are activated, and residential and recruited monocytederived macrophages are crucial for evoking and resolving the acute inflammatory reaction. Dendritic cell mobilization is stimulated by VEGF produced by B cells in inflamed lymph nodes (Angeli et al. 2006), and inflamed lymphatic endothelium can suppress dendritic cell maturation through a Mac-1/ICAM-1-dependent mechanism (Podgrabinska et al. 2009).

Lymphangiogenesis occurs at sites of tissue inflammation, and macrophages express VEGF-C and VEGF-D, which contribute to lymphatic vessel formation during inflammation (Cursiefen et al. 2004; Maruyama et al. 2005; Kerjaschki et al. 2006). For example, lymphangiogenesis is associated with inflammatory angiogenesis in the rabbit cornea, and the angiogenic and lymphangiogenic responses are blocked by depleting macrophages, a result suggesting that inflammatory cells mediate lymphatic vessel formation (Cursiefen et al. 2004). In fact, CD11b ${ }^{+}$macrophages are involved in inflammation-induced lymphangiogenic growth in the cornea (Maruyama et al. 2005). Furthermore, during inflammatory conditions such as penetrating keratoplasty in the mouse cornea, $\mathrm{CD}_{1} 1 \mathrm{~b}^{+}$macrophages can transdifferentiate into LECs and contribute to lymphangiogenesis in the corneal stroma (Maruyama et al. 2005). However, no evidence is yet available supporting a role for macrophages during developmental lymphangiogenesis or normal noninflammatory conditions (Srinivasan et al. 2007; Bertozzi et al. 2010).

Edema occurs in asthma and other inflammatory diseases when the rate of plasma leakage from blood vessels exceeds the drainage through lymphatic vessels and other routes. Extensive lymphangiogenesis promoted by VEGFC- and VEGF-D-producing inflammatory cells was observed in a mouse model of chronic airway inflammation induced by Mycoplasma pulmonis infection (Baluk et al. 2005). In this model, inhibiting VEGFR3-mediated signaling prevented the growth of lymphatic vessels, leading to 
bronchial lymphedema and airflow obstruction (Baluk et al. 2005). Therefore, it is argued that defective lymphangogenesis during airway inflammation may lead to bronchial lymphedema and exaggerated airflow stagnation (Baluk et al. 2005). In the same animal model, airway inflammation leads to increased tumor necrosis factor $\alpha$ (TNF- $\alpha$ ) expression, and inhibiting TNF- $\alpha$ signaling results in significantly reduced lymphangiogenesis (Baluk et al. 2009). Therefore, TNF- $\alpha$ might require inflammatory mediators from recruited leukocytes to fulfill its role in inflammation-mediated lymphangiogenesis (Baluk et al. 2009).

Lymphangiogenesis was also reported in cases of chronic inflammation such as psoriasis and rheumatoid arthritis (Kunstfeld et al. 2004; Kajiya and Detmar 2006; Tammela and Alitalo 2010), and in cases of kidney transplant rejection in which the newly formed lymphatic vessels produce the chemokine CCL21, which attracts CCR7-positive dendritic cells that might promote the inflammatory reaction (Kerjaschki et al. 2004). Consistent with the antiinflammatory role of transforming growth factor $\beta$ (TGF- $\beta$ ), recent results revealed that TGF- $\beta$ signaling acts as a lymphangiogenesis inhibitor in inflammatory settings (Clavin et al. 2008; Oka et al. 2008).

At the molecular level, the main mediators of the inflammatory response are transcription factors of the

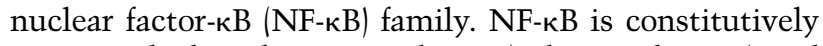
active in the lymphatic vasculature (Saban et al. 2004), and in vitro analysis suggests that induction of the NF- $\mathrm{kB}$ pathway by inflammatory stimuli activates the transcription factor Prox1, which acts with NF-кB to activate VEGFR3 (Flister et al. 2010). Proxl (a key regulator in the pathway leading to LEC specification) and VEGF-C (the VEGFR3 ligand) are both required to form the lymphatic network (Wigle and Oliver 1999; Wigle et al. 2002; Karkkainen et al. 2004). In an inflammatory setting, the elevated VEGFR3 expression promoted by the induction of NF- $\mathrm{kB}$ signaling increases the sensitivity of the pre-existing lymphatic endothelium to VEGF-C and VEGF-D, leading to enhanced lymphangiogenesis (Flister et al. 2010). Furthermore, in cultured T cells, interferon $\gamma$, a major proinflammatory effector, is repressed by Prox1 in cooperation with peroxisome proliferator-activated receptor $\gamma$ (Wang et al. 2008). Together, these findings revealed a series of novel mechanisms underlying inflammatory lymphangiogenesis that should be relevant in therapeutic approaches aimed at eliminating the rejection reaction after organ transplantation and treating inflammatory airway diseases.

\section{Lymphatic vasculature and tumor metastasis}

In most human cancers, the lymphatic vasculature serves as the primary route for the metastatic spread of tumor cells to regional lymph nodes (Van den Eynden et al. 2007; Bolenz et al. 2009; Gao et al. 2009; Kodama et al. 2010). Additionally, metastatic node status represents a major criterion for staging, treatment, and prognosis for many types of solid tumors. However, despite the importance of tumor-associated lymphatic vessels for cancer progression, not much information is yet available about the cellular and molecular mechanisms involved in lymphatic metastasis.

Tumor cells access the lymphatic vasculature by invading the pre-existing lymphatic vessels in the tumor margin or promoting lymphangiogenesis (Achen et al. 2005; Tobler and Detmar 2006). In some types of cancer, malignant tumor cells may have an active role in inducing peritumoral and intratumoral lymphangiogenesis (He et al. 2005; Hoshida et al. 2006).

Several studies have shown that VEGF-C/D expression facilitates tumor-associated lymphangiogenesis and promotes lymph node metastasis (Karpanen et al. 2001; Mandriota et al. 2001; Skobe et al. 2001; Stacker et al. 2001; Arigami et al. 2009; Lahat et al. 2009; Sugiura et al. 2009). Blocking VEGF-D or VEGF-C to VEGFR3 signaling inhibits both tumor-associated lymphangiogenesis and lymph node metastasis (Fig. 3; Karpanen et al. 2001; Mandriota et al. 2001; Stacker et al. 2001; He et al. 2005; Lin et al. 2005; Hoshida et al. 2006; Roberts et al. 2006). In line with these results, expressing siRNA targeted against VEGF-C in mouse breast cancer cells inhibits lymph node metastasis (Chen et al. 2005; Shibata et al. 2008). In addition, blocking the binding of VEGF-C to its coreceptor, neuropilin-2 (Nrp2), reduces VEGF-C-induced LEC migration as well as tumor-associated lymphangiogenesis (Caunt et al. 2008).

Recent results revealed that lymphangiogenesis is not only involved in lymph node metastasis, but also contributes to distant metastasis. For example, in the case of lung tumors, work by Das et al. (2010) has shown recently that, in addition to its effects in the primary tumor site and the lymph nodes, VEGF-C activity in the lung tissue also impact the metastatic progression. These data indicate that VEGF-C-VEGFR3 signaling may be a potential target for the treatment of metastatic tumors. Several independent studies have shown that lymph node lymphangiogenesis may promote tumor metastasis (Dadras et al. 2005; Hirakawa et al. 2005, 2007, 2009; Harrell et al. 2007; Van den Eynden et al. 2007). Interestingly, it appears that tumors can induce lymph node lymphangiogenesis at a distance, as tumor-associated lymphangiogenesis in lymph nodes starts even prior to tumor dissemination (Fig. 3; Hirakawa et al. 2005, 2007; Harrell et al. 2007). However, a possible role of lymph node lymphangiogenesis in facilitating distant tumor metastasis still needs to be determined.

There is an increasing amount of evidence highlighting the involvement of the CC chemokine receptor 7 (CCR7) in tumor metastasis (Muller et al. 2001; Wiley et al. 2001; Issa et al. 2009). It has been shown recently that tumor cells can produce both VEGF-C and CCR7, which act cooperatively to promote lymphatic invasion (Issa et al. 2009). In addition to inducing lymphangiogenesis, tumorsecreted VEGF-C up-regulates the expression of CCL21, the ligand of CCR7, in LECs to attract CCR7-expressing tumor cells to lymphatic vessels. VEGF-C can also promote proteolytic activity and motility of tumor cells, and, therefore, enhance tumor cell invasion (Issa et al. 2009). Moreover, tumor-associated macrophages (TAMs) in peritumoral stroma produce VEGF-C and VEGF-D, contributing to 
A

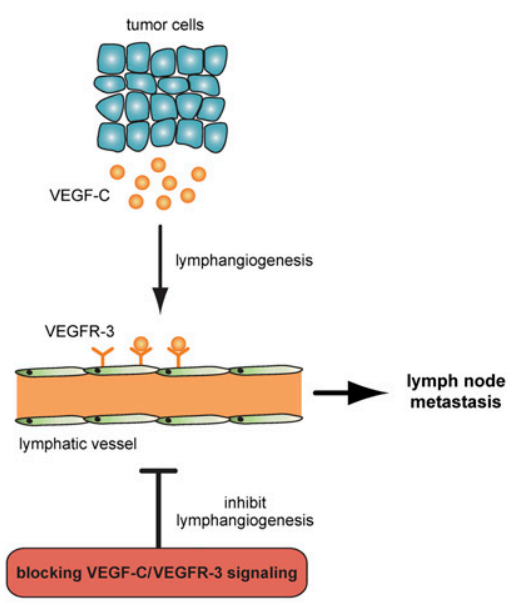

Tumor lymphangiogenesis
B

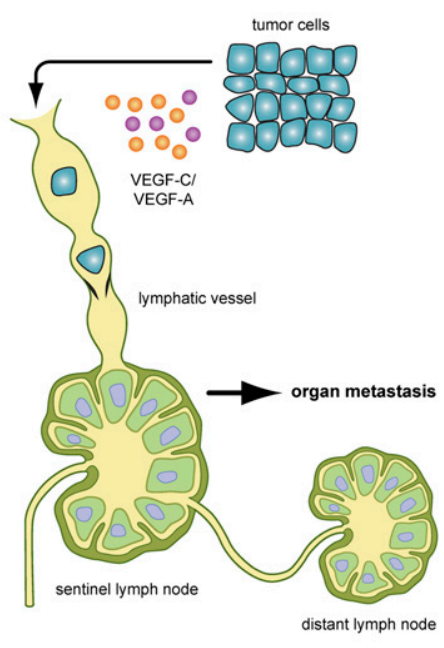

Lymph node lymphangiogenesis

Figure 3. Lymph nodes are the most common site for the metastatic spread of tumor cells, and tumor propagation to lymph nodes is one of the main prognostic indicators. As tumor cells reach the sentinel lymph node, they will spread into distant lymph nodes and other organs. (A) One of the mechanisms of tumor-associated lymphangiogenesis involves the release of VEGF-C or VEGF-D by tumor cells or TAMs, stimulating the growth of additional peritumoral (and, in some cases, also intratumoral) lymphatic vessels and the dilation of preexisting lymphatic vessels. This in turn facilitates the entry of tumor cells into the lumen of the lymphatic vessels, possibly via interactions between tumor cells and LECs. Therefore, inhibition of tumor lymphangiogenesis by blocking the VEGF-C/VEGFR-3 signaling pathway could be an efficient approach aimed to suppress lymph node metastasis. (B) Lymph node lymphangiogenesis has also been shown recently to promote tumor metastasis. In this case, growth factors such as VEGF-C or VEGF-A produced by the primary tumor can act at a distance by inducing lymphangiogenesis in the sentinel lymph node prior to the arrival of the first metastatic cells and, eventually, promoting additional cancer metastasis to distant lymph nodes and organs.

peritumoral lymphangiogenesis and tumor metastasis (Schoppmann et al. 2002). In addition, Kubota et al. (2009) have demonstrated that macrophage colony-stimulating factor (M-CSF), a cytokine required for monocyte lineage cell differentiation, promotes the formation of high-density vessels in tumors (Kubota et al. 2009). Inhibiting M-CSF specifically suppresses tumor-associated angiogenesis and lymphangiogenesis, suggesting that M-CSF might be a target for anti-cancer treatment (Kubota et al. 2009).

Although peritumoral lymphatic vessels are functional, the presence and significance of lymphatic vessels within tumors is still controversial. For example, it has been argued that, because of high intratumoral pressure, intratumoral lymphatics might not be functional or required for lymphatic metastasis (Jain 1989; Padera et al. 2002; Wong et al. 2005). However, others have found that intratumoral lymphatic vessel density is significantly associated with lymphatic invasion (Kyzas et al. 2005).

\section{Lymphatic vasculature and Kaposi's sarcoma (KS)}

KS is the most common malignant tumor in AIDS patients infected with human immunodeficiency virus (HIV) (Hong et al. 2004; Wang et al. 2004). KS is a highly vascularized tumor whose formation requires infection with KS-associated herpesvirus (KSHV, also known as human herpesvirus-8). In KS tumors, spindle cells (i.e., cells of endothelial origin) are the most common cells, and they were shown to express the LEC markers podoplanin and VEGFR3 (Jussila et al. 1998; Skobe et al. 1999; Carroll et al. 2004). Infecting blood vascular ECs (BECs) with KSHV is sufficient to reprogram them into LECs in vitro (Carroll et al. 2004; Hong et al. 2004; Wang et al. 2004). In addition, it was shown previously that Proxl is sufficient to reprogram cultured BECs into LECs by repressing $40 \%$ of BEC-specific genes and inducing the expression of $\sim 20 \%$ of LEC-specific genes (Hong et al. 2002; Petrova et al. 2002). In line with those findings, BEC-to-LEC reprogramming promoted by KSHV infection is associated with up-regulated Proxl expression in infected cells, and inactivating Prox1 blocks this reprogramming (Hong et al. 2004). These results suggest that KSHV infection of BECs leads to their reprogramming into LECs as they transform into spindle cells (Carroll et al. 2004). Increased serum levels of the lymphangiogenic factors VEGF-D and angiopoietin-2 have been detected in patients with AIDS and KS (Wang et al. 2004). As an extension of this initial work, Dadras et al. (2008) demonstrated recently that Proxl expression is sufficient to induce more aggressive behavior of KS tumors growing in syngenic mice; this observation was associated with up-regulation in the expression of genes involved in proteolysis, cell adhesion, and migration.

\section{Novel functions of the lymphatic vasculature}

\section{Fat metabolism}

The lymphatic vasculature is essential for the adsorption of lipids from the intestine. In the 17th century, Aselli (1627) observed the mesenteric lymphatics (structures that he named the venae alba et lacteae; i.e., white veins) in dogs who had consumed a lipid-rich meal. The lipidrich content of the mesenteric lymphatics (lacteals) is drained via the cisterna chyli and thoracic duct back into the bloodstream. The lipid-rich intestinal content is packaged by the absorptive cells of the small intestine (i.e., enterocytes) into water-soluble particles named chylomicrons.

The fact that, for example, lymph nodes are normally surrounded by adipose tissue and subcutaneous adipose tissue lies in close proximity to the dermal lymphatic vasculature suggested a relationship between lymphatic 
vessels and adipose metabolism. Additionally, ectopic adipose tissue growth is observed in edematous regions of patients suffering from chronic lymphedema (Brorson 2003), and lymph or chyle (i.e., a mixture of lymph and chylomicrons with a milky appearance) promotes the differentiation of rabbit preadipocytes in vitro (Nougues et al. 1988). Furthermore, a correlation between immune cells, lymph nodes, and their surrounding adipose tissue has been documented (Pond and Mattacks 1995, 2003; Pond 2003). In rats, chronic inflammation of the peripheral lymph nodes increases the number of adipocytes surrounding the nodes (Mattacks et al. 2003). Additional work by Mattacks et al. (2003) demonstrated that adipocytes within the lymph node fat pads that are most closely apposed to the lymph node respond to local immune challenge by increasing their rate of lipolysis.

In the case of human pathologies, lipedema is a chronic syndome that arises almost exclusively in post-pubertal females and causes characteristic swelling of the bilateral and symmetric lower extremities as a consequence of excess subcutaneous fat deposition, although the feet remain normal (Rudkin and Miller 1994; Bilancini et al. 1995; Fonder et al. 2007; Harvey 2008; Suga et al. 2009). Defective lymphatic vasculature should not be ruled out as a leading cause of this disease because functional alterations in lymph flow (Bilancini et al. 1995) and microlymphatic aneurysms (Amann-Vesti et al. 2001) have been described in the skin of patients with lipedema.

Despite all of these well-established connections between lymphatics and lipids, the role of the lymphatic vasculature in adipose metabolism has only recently begun to be recognized.

Increased deposition of subcutaneous fat in edematous regions has been observed in Chy mice carrying a heterozygous inactivating mutation in VEGFR3 (Karkkainen et al. 2001). These mice exhibit lymphedema as a result of hypoplastic cutaneous lymphatic vessels (Karkkainen et al. 2001). This finding supports the hypothesis that the lymph is adipogenic.

A correlation between late-onset obesity and the lymphatic vasculature has been demonstrated in a mouse model of defective lymphatic vasculature providing the strongest direct evidence of a link between lymphatics and fat metabolism. In this model, Harvey et al. (2005) demonstrated that Prox1 haploinsufficiency promotes lymphatic vascular defects that cause adult-onset obesity (Fig. 2); therefore, Prox1 heterozygous mice serve as the first in vivo model of lymphatic-mediated obesity (Harvey et al. 2005; Harvey 2008). The leading cause of the obese phenotype resulting from Prox1 haploinsufficiency is abnormal lymph leakage due to a disruption in lymphatic vascular integrity, particularly of the mesenteric lymphatic vessels (Fig. 2; Harvey et al. 2005). Furthermore, the lymph was capable of promoting adipogenic differentiation of mouse 3T3-L1 preadipocytes, leading to the proposal that disruption of lymphatic vascular integrity promotes the ectopic growth of fat in lymphaticrich regions because of increased lipid storage in adipocytes and increased differentiation of preadipocytes to mature adipocytes (Harvey et al. 2005).
In Prox $1^{+/-}$mice, adipose tissue accumulation is associated with an increased number of LYVE-1-positive macrophages in the mesentery (Harvey et al. 2005). This finding is interesting because numerous observations suggest that inflammatory factors may underlie metabolic diseases such as obesity. In fact, macrophages infiltrate adipose tissue in obesity conditions (Weisberg et al. 2003; $\mathrm{Xu}$ et al. 2003) and promote lymphangiogenesis in mouse models of inflammatory disease. Accordingly, the inflammatory process described in Prox $1^{+-}$mice may have contributed to adipose tissue accumulation in this mouse model (Harvey et al. 2005).

Finally, a recent study using hypercholesterolemic apolipoprotein E (apoE)-null mice revealed that the hypercholesterolemia in these mice is associated with tissue swelling, lymphatic leakiness, and decreased lymphatic transport of fluid (Lim et al. 2009). In these animals, the mutant capillary lymphatic vessels are significantly dilated and the collecting vessels show remarkably reduced smooth muscle cell recruitment (Lim et al. 2009). These data suggested that hypercholesterolemia in apoE-null mice is associated with lymphatic vessel dysfunction. In the next few years, researchers should strive to determine whether some forms of lymphatic dysfunction are responsible for human obesity syndromes.

\section{Hypertension}

A high-salt diet (HSD) is one of the causes of hypertension. A recent work has demonstrated that, in HSDs, lymphatic vessels play a role in blood pressure buffering (Fig. 2; Machnik et al. 2009). This process is mediated by mononuclear phagocyte system (MPS)-driven tonicityresponsive enhancer-binding protein (TonEBP) and VEGF$\mathrm{C}$ signaling. This signaling induces lymphatic vessel hyperplasia, resulting in increased lymphatic drainage capacity, and thus contributes to interstitial fluid and blood pressure homeostasis (Machnik et al. 2009). In mice fed with HSDs, $\mathrm{Na}^{+}$accumulates in the interstitium of the skin, leading to hyperplasia of lymphatic vessels: This hyperplasia is promoted by VEGF-C that is secreted from MPS cells (Machnik et al. 2009). Additionally, individuals with refractory hypertension have higher concentrations of plasma VEGF-C (Machnik et al. 2009). These findings suggest that deregulation of TonEBP-VEGF-C signaling may be related to hypertension in humans, and that lymphatic vessel hyperplasia is required to regulate salt storage in the interstitium. Alternatively, HSD-caused hypertension might up-regulate TonEBP-VEGF-C signaling to compensate for elevated blood pressure by promoting lymphangiogenesis.

\section{Perspectives}

Our knowledge of lymphatic vasculature-associated diseases has been expanded significantly in the last few years, mainly because of the identification of novel regulators of the lymphatic vasculature and the generation of valuable animal models. As this flow of new information continues, we should expect to uncover novel molecular 
mechanisms underlying pathologic processes that could facilitate the design of therapeutic strategies against cancer, inflammatory conditions, and metabolic diseases.

\section{Acknowledgments}

We thank S. Srinivasan and J. Yang for critical reading of this manuscript, C. Guess for editing of the manuscript, and J. Anderson and B. Williford for help with the figures.

\section{References}

Achen MG, Jeltsch M, Kukk E, Makinen T, Vitali A, Wilks AF, Alitalo K, Stacker SA. 1998. Vascular endothelial growth factor D (VEGF-D) is a ligand for the tyrosine kinases VEGF receptor 2 (Flk1) and VEGF receptor 3 (Flt4). Proc Natl Acad Sci 95: 548-553.

Achen MG, McColl BK, Stacker SA. 2005. Focus on lymphangiogenesis in tumor metastasis. Cancer Cell 7: 121-127.

Adams RH, Alitalo K. 2007. Molecular regulation of angiogenesis and lymphangiogenesis. Nat Rev Mol Cell Biol 8: 464478.

Alders M, Hogan BM, Gjini E, Salehi F, Al-Gazali L, Hennekam EA, Holmberg EE, Mannens MM, Mulder MF, Offerhaus GJ, et al. 2009. Mutations in CCBE1 cause generalized lymph vessel dysplasia in humans. Nat Genet 41: 1272-1274.

Amann-Vesti BR, Franzeck UK, Bollinger A. 2001. Microlymphatic aneurysms in patients with lipedema. Lymphology 34: 170-175.

Angeli V, Ginhoux F, Llodra J, Quemeneur L, Frenette PS, Skobe M, Jessberger R, Merad M, Randolph GJ. 2006. B cell-driven lymphangiogenesis in inflamed lymph nodes enhances dendritic cell mobilization. Immunity 24: 203-215.

Arigami T, Natsugoe S, Uenosono Y, Yanagita S, Ehi K, Arima H, Mataki Y, Nakajo A, Ishigami S, Aikou T. 2009. Vascular endothelial growth factor-C and -D expression correlates with lymph node micrometastasis in pNO early gastric cancer. I Surg Oncol 99: 148-153.

Aselli G. 1627. De Lacteibus sive Lacteis Venis, Quarto Vasorum Mesarai corum Genere novo invento. Mediolani, Milan.

Baluk P, Tammela T, Ator E, Lyubynska N, Achen MG, Hicklin DJ, Jeltsch M, Petrova TV, Pytowski B, Stacker SA, et al. 2005. Pathogenesis of persistent lymphatic vessel hyperplasia in chronic airway inflammation. J Clin Invest 115: 247-257.

Baluk P, Yao LC, Feng J, Romano T, Jung SS, Schreiter JL, Yan L, Shealy DJ, McDonald DM. 2009. TNF- $\alpha$ drives remodeling of blood vessels and lymphatics in sustained airway inflammation in mice. J Clin Invest 119: 2954-2964.

Bazigou E, Xie S, Chen C, Weston A, Miura N, Sorokin L, Adams R, Muro AF, Sheppard D, Makinen T. 2009. Integrin- $\alpha 9$ is required for fibronectin matrix assembly during lymphatic valve morphogenesis. Dev Cell 17: 175-186.

Bellini C, Boccardo F, Campisi C, Bonioli E. 2006. Congenital pulmonary lymphangiectasia. Orphanet I Rare Dis 1: 43.

Bertozzi CC, Schmaier AA, Mericko P, Hess PR, Zou Z, Chen M, Chen CY, Xu B, Lu MM, Zhou D, et al. 2010. Platelets regulate lymphatic vascular development through CLEC2-SLP-76 signaling. Blood 116: 661-670.

Bilancini S, Lucchi M, Tucci S, Eleuteri P. 1995. Functional lymphatic alterations in patients suffering from lipedema. Angiology 46: 333-339.

Bolenz C, Fernandez MI, Trojan L, Hoffmann K, Herrmann E, Steidler A, Weiss C, Strobel P, Alken P, Michel MS. 2009. Lymphangiogenesis occurs in upper tract urothelial carcinoma and correlates with lymphatic tumour dissemination and poor prognosis. BJU Int 103: 1040-1046.
Brice G, Mansour S, Bell R, Collin JR, Child AH, Brady AF, Sarfarazi M, Burnand KG, Jeffery S, Mortimer P, et al. 2002. Analysis of the phenotypic abnormalities in lymphoedemadistichiasis syndrome in 74 patients with FOXC2 mutations or linkage to 16q24. J Med Genet 39: 478-483.

Brorson H. 2003. Liposuction in arm lymphedema treatment. Scand J Surg 92: 287-295.

Bull LN, Roche E, Song EJ, Pedersen J, Knisely AS, van Der Hagen CB, Eiklid K, Aagenaes O, Freimer NB. 2000. Mapping of the locus for cholestasis-lymphedema syndrome (Aagenaes syndrome) to a $6.6-\mathrm{cM}$ interval on chromosome $15 \mathrm{q}$. Am I Hum Genet 67: 994-999.

Carroll PA, Brazeau E, Lagunoff M. 2004. Kaposi's sarcomaassociated herpesvirus infection of blood endothelial cells induces lymphatic differentiation. Virology 328: 7-18.

Caunt M, Mak J, Liang WC, Stawicki S, Pan Q, Tong RK, Kowalski J, Ho C, Reslan HB, Ross J, et al. 2008. Blocking neuropilin-2 function inhibits tumor cell metastasis. Cancer Cell 13: 331-342.

Chen Z, Varney ML, Backora MW, Cowan K, Solheim JC, Talmadge JE, Singh RK. 2005. Down-regulation of vascular endothelial cell growth factor-C expression using small interfering RNA vectors in mammary tumors inhibits tumor lymphangiogenesis and spontaneous metastasis and enhances survival. Cancer Res 65: 9004-9011.

Clavin NW, Avraham T, Fernandez J, Daluvoy SV, Soares MA, Chaudhry A, Mehrara BJ. 2008. TGF- $\beta 1$ is a negative regulator of lymphatic regeneration during wound repair. Am J Physiol Heart Circ Physiol 295: H2113-H2127. doi: 10.1152/ ajpheart.00879.2008.

Cursiefen C, Chen L, Borges LP, Jackson D, Cao J, Radziejewski C, D'Amore PA, Dana MR, Wiegand SJ, Streilein JW. 2004. VEGF-A stimulates lymphangiogenesis and hemangiogenesis in inflammatory neovascularization via macrophage recruitment. J Clin Invest 113: 1040-1050.

Dadras SS, Lange-Asschenfeldt B, Velasco P, Nguyen L, Vora A, Muzikansky A, Jahnke K, Hauschild A, Hirakawa S, Mihm $\mathrm{MC}$, et al. 2005. Tumor lymphangiogenesis predicts melanoma metastasis to sentinel lymph nodes. Mod Pathol 18: 1232-1242.

Dadras SS, Skrzypek A, Nguyen L, Shin JW, Schulz MM, Arbiser J, Mihm MC, Detmar M. 2008. Prox-1 promotes invasion of kaposiform hemangioendotheliomas. I Invest Dermatol 128: 2798-2806.

Das S, Ladell DS, Podgrabinska S, Ponomarev V, Nagi C, Fallon JT, Skobe M. 2010. Vascular endothelial growth factor-C induces lymphangitic carcinomatosis, an extremely aggressive form of lung metastases. Cancer Res 70: 18141824.

Falls HF, Kertesz ED. 1964. A new syndrome combining pterygium colli with developmental anomalies of the eyelids and lymphatics of the lower extremities. Trans Am Ophthalmol Soc 62: 248-275.

Fang I, Dagenais SL, Erickson RP, Arlt MF, Glynn MW, Gorski JL, Seaver LH, Glover TW. 2000. Mutations in FOXC2 (MFH1), a forkhead family transcription factor, are responsible for the hereditary lymphedema-distichiasis syndrome. Am J Hum Genet 67: 1382-1388.

Faul JL, Berry GJ, Colby TV, Ruoss SJ, Walter MB, Rosen GD, Raffin TA. 2000. Thoracic lymphangiomas, lymphangiectasis, lymphangiomatosis, and lymphatic dysplasia syndrome. Am J Respir Crit Care Med 161: 1037-1046.

Ferrell RE, Levinson KL, Esman JH, Kimak MA, Lawrence EC, Barmada MM, Finegold DN. 1998. Hereditary lymphedema: Evidence for linkage and genetic heterogeneity. Hum Mol Genet 7: 2073-2078. 
Finegold DN, Kimak MA, Lawrence EC, Levinson KL, Cherniske EM, Pober BR, Dunlap JW, Ferrell RE. 2001. Truncating mutations in FOXC2 cause multiple lymphedema syndromes. Hum Mol Genet 10: 1185-1189.

Flamme I, Frolich T, Risau W. 1997. Molecular mechanisms of vasculogenesis and embryonic angiogenesis. I Cell Physiol 173: 206-210.

Flister MJ, Wilber A, Hall KL, Iwata C, Miyazono K, Nisato RE, Pepper MS, Zawieja DC, Ran S. 2010. Inflammation induces lymphangiogenesis through up-regulation of VEGFR-3 mediated by NF-кB and Prox1. Blood 115: 418-429.

Fonder MA, Loveless JW, Lazarus GS. 2007. Lipedema, a frequently unrecognized problem. J Am Acad Dermatol 57: S1S3. doi: 10.1016/j.jaad.2006.09.023.

Francois M, Caprini A, Hosking B, Orsenigo F, Wilhelm D, Browne C, Paavonen K, Karnezis T, Shayan R, Downes M, et al. 2008. Sox18 induces development of the lymphatic vasculature in mice. Nature 456: 643-647.

Gao P, Zhou GY, Zhang QH, Su ZX, Zhang TG, Xiang L, Wang Y, Zhang SL, Mu K. 2009. Lymphangiogenesis in gastric carcinoma correlates with prognosis. J Pathol 218: 192-200.

Harrell MI, Iritani BM, Ruddell A. 2007. Tumor-induced sentinel lymph node lymphangiogenesis and increased lymph flow precede melanoma metastasis. Am J Pathol 170: 774786.

Harvey NL. 2008. The link between lymphatic function and adipose biology. Ann N Y Acad Sci 1131: 82-88.

Harvey NL, Oliver G. 2004. Choose your fate: Artery, vein or lymphatic vessel? Curr Opin Genet Dev 14: 499-505.

Harvey NL, Srinivasan RS, Dillard ME, Johnson NC, Witte MH, Boyd K, Sleeman MW, Oliver G. 2005. Lymphatic vascular defects promoted by Prox 1 haploinsufficiency cause adultonset obesity. Nat Genet 37: 1072-1081.

He Y, Rajantie I, Pajusola K, Jeltsch M, Holopainen T, YlaHerttuala S, Harding T, Jooss K, Takahashi T, Alitalo K. 2005. Vascular endothelial cell growth factor receptor 3mediated activation of lymphatic endothelium is crucial for tumor cell entry and spread via lymphatic vessels. Cancer Res 65: 4739-4746.

Hirakawa S, Kodama S, Kunstfeld R, Kajiya K, Brown LF, Detmar M. 2005. VEGF-A induces tumor and sentinel lymph node lymphangiogenesis and promotes lymphatic metastasis. J Exp Med 201: 1089-1099.

Hirakawa S, Brown LF, Kodama S, Paavonen K, Alitalo K, Detmar M. 2007. VEGF-C-induced lymphangiogenesis in sentinel lymph nodes promotes tumor metastasis to distant sites. Blood 109: 1010-1017.

Hirakawa S, Detmar M, Kerjaschki D, Nagamatsu S, Matsuo K, Tanemura A, Kamata N, Higashikawa K, Okazaki H, Kameda K, et al. 2009. Nodal lymphangiogenesis and metastasis: Role of tumor-induced lymphatic vessel activation in extramammary Paget's disease. Am I Pathol 175: 22352248.

Hoerauf A, Mand S, Fischer K, Kruppa T, Marfo-Debrekyei Y, Debrah AY, Pfarr KM, Adjei O, Buttner DW. 2003. Doxycycline as a novel strategy against bancroftian filariasis-depletion of Wolbachia endosymbionts from Wuchereria bancrofti and stop of microfilaria production. Med Microbiol Immunol (Berl) 192: 211-216.

Hogan BM, Bos FL, Bussmann J, Witte M, Chi NC, Duckers HJ, Schulte-Merker S. 2009. Ccbe1 is required for embryonic lymphangiogenesis and venous sprouting. Nat Genet 41: 396-398.

Hokari R, Kitagawa N, Watanabe C, Komoto S, Kurihara C, Okada Y, Kawaguchi A, Nagao S, Hibi T, Miura S. 2008. Changes in regulatory molecules for lymphangiogenesis in intestinal lymphangiectasia with enteric protein loss. J Gastroenterol Hepatol 23: e88-e95. doi: 10.1111/j.1440-1746.2007.05225.x.

Hong SE, Shugart YY, Huang DT, Shahwan SA, Grant PE, Hourihane JO, Martin ND, Walsh CA. 2000. Autosomal recessive lissencephaly with cerebellar hypoplasia is associated with human RELN mutations. Nat Genet 26: 93-96.

Hong YK, Harvey N, Noh YH, Schacht V, Hirakawa S, Detmar M, Oliver G. 2002. Proxl is a master control gene in the program specifying lymphatic endothelial cell fate. Dev Dyn 225: 351-357.

Hong YK, Foreman K, Shin JW, Hirakawa S, Curry CL, Sage DR, Libermann T, Dezube BJ, Fingeroth JD, Detmar M. 2004. Lymphatic reprogramming of blood vascular endothelium by Kaposi sarcoma-associated herpesvirus. Nat Genet 36: 683685.

Hoshida T, Isaka N, Hagendoorn J, di Tomaso E, Chen YL, Pytowski B, Fukumura D, Padera TP, Jain RK. 2006. Imaging steps of lymphatic metastasis reveals that vascular endothelial growth factor-C increases metastasis by increasing delivery of cancer cells to lymph nodes: Therapeutic implications. Cancer Res 66: 8065-8075.

Huang XZ, Wu JF, Ferrando R, Lee JH, Wang YL, Farese RV Jr, Sheppard D. 2000. Fatal bilateral chylothorax in mice lacking the integrin $\alpha 9 \beta 1$. Mol Cell Biol 20: 5208-5215.

Irrthum A, Karkkainen MJ, Devriendt K, Alitalo K, Vikkula M. 2000. Congenital hereditary lymphedema caused by a mutation that inactivates VEGFR3 tyrosine kinase. Am I Hum Genet 67: 295-301.

Irrthum A, Devriendt K, Chitayat D, Matthijs G, Glade C, Steijlen PM, Fryns JP, Van Steensel MA, Vikkula M. 2003. Mutations in the transcription factor gene SOX18 underlie recessive and dominant forms of hypotrichosis-lymphedema-telangiectasia. Am J Hum Genet 72: 1470-1478.

Issa A, Le TX, Shoushtari AN, Shields JD, Swartz MA. 2009. Vascular endothelial growth factor-C and C-C chemokine receptor 7 in tumor cell-lymphatic cross-talk promote invasive phenotype. Cancer Res 69: 349-357.

Issaka RB, Oommen S, Gupta SK, Liu G, Myers JL, Ryu JH, Vlahakis NE. 2009. Vascular endothelial growth factors C and $\mathrm{D}$ induces proliferation of lymphangioleiomyomatosis cells through autocrine crosstalk with endothelium. Am J Pathol 175: 1410-1420.

Jain RK. 1989. Delivery of novel therapeutic agents in tumors: Physiological barriers and strategies. J Natl Cancer Inst 81: 570-576.

Jamieson T, Cook DN, Nibbs RJ, Rot A, Nixon C, McLean P, Alcami A, Lira SA, Wiekowski M, Graham GJ. 2005. The chemokine receptor D6 limits the inflammatory response in vivo. Nat Immunol 6: 403-411.

Johnson NC, Oliver G. 2009. Insight into lymphatic vasculature development. In Lymphangiogenesis in cancer metastasis (ed. SA Stacker and MG Achen), pp. 11-25. Springer, Dordrecht.

Joukov V, Pajusola K, Kaipainen A, Chilov D, Lahtinen I, Kukk E, Saksela O, Kalkkinen N, Alitalo K. 1996. A novel vascular endothelial growth factor, VEGF-C, is a ligand for the Flt4 (VEGFR-3) and KDR (VEGFR-2) receptor tyrosine kinases. EMBO J 15: 1751.

Joukov V, Sorsa T, Kumar V, Jeltsch M, Claesson-Welsh L, Cao Y, Saksela O, Kalkkinen N, Alitalo K. 1997. Proteolytic processing regulates receptor specificity and activity of VEGF-C. EMBO J 16: 3898-3911.

Jussila L, Valtola R, Partanen TA, Salven P, Heikkila P, Matikainen MT, Renkonen R, Kaipainen A, Detmar M, Tschachler E, et al. 1998. Lymphatic endothelium and Kaposi's sarcoma spindle cells detected by antibodies against the vascular endothelial growth factor receptor-3. Cancer Res 58: 1599-1604. 
Juvet SC, Hwang D, Downey GP. 2006. Rare lung diseases I-Lymphangioleiomyomatosis. Can Respir J 13: 375-380.

Juvet SC, McCormack FX, Kwiatkowski DJ, Downey GP. 2007. Molecular pathogenesis of lymphangioleiomyomatosis: Lessons learned from orphans. Am I Respir Cell Mol Biol 36: 398-408.

Kajiya K, Detmar M. 2006. An important role of lymphatic vessels in the control of UVB-induced edema formation and inflammation. I Invest Dermatol 126: 919-921.

Karkkainen MJ, Ferrell RE, Lawrence EC, Kimak MA, Levinson KL, McTigue MA, Alitalo K, Finegold DN. 2000. Missense mutations interfere with VEGFR-3 signalling in primary lymphoedema. Nat Genet 25: 153-159.

Karkkainen MJ, Saaristo A, Jussila L, Karila KA, Lawrence EC, Pajusola K, Bueler H, Eichmann A, Kauppinen R, Kettunen MI, et al. 2001. A model for gene therapy of human hereditary lymphedema. Proc Natl Acad Sci 98: 12677-12682.

Karkkainen MJ, Haiko P, Sainio K, Partanen J, Taipale J, Petrova TV, Jeltsch M, Jackson DG, Talikka M, Rauvala H, et al. 2004. Vascular endothelial growth factor $\mathrm{C}$ is required for sprouting of the first lymphatic vessels from embryonic veins. Nat Immunol 5: 74-80.

Karpanen T, Alitalo K. 2008. Molecular biology and pathology of lymphangiogenesis. Annu Rev Pathol 3: 367-397.

Karpanen T, Egeblad M, Karkkainen MJ, Kubo H, Yla-Herttuala S, Jaattela M, Alitalo K. 2001. Vascular endothelial growth factor C promotes tumor lymphangiogenesis and intralymphatic tumor growth. Cancer Res 61: 1786-1790.

Kerjaschki D, Regele HM, Moosberger I, Nagy-Bojarski K, Watschinger B, Soleiman A, Birner P, Krieger S, Hovorka A, Silberhumer G, et al. 2004. Lymphatic neoangiogenesis in human kidney transplants is associated with immunologically active lymphocytic infiltrates. I Am Soc Nephrol 15: 603-612.

Kerjaschki D, Huttary N, Raab I, Regele H, Bojarski-Nagy K, Bartel G, Krober SM, Greinix H, Rosenmaier A, Karlhofer F, et al. 2006. Lymphatic endothelial progenitor cells contribute to de novo lymphangiogenesis in human renal transplants. Nat Med 12: 230-234.

Kodama M, Kitadai Y, Sumida T, Ohnishi M, Ohara E, Tanaka M, Shinagawa K, Tanaka S, Yasui W, Chayama K. 2010. Expression of platelet-derived growth factor (PDGF)-B and PDGF-receptor $\beta$ is associated with lymphatic metastasis in human gastric carcinoma. Cancer Sci 101: 1984-1989.

Kubota Y, Takubo K, Shimizu T, Ohno H, Kishi K, Shibuya M, Saya H, Suda T. 2009. M-CSF inhibition selectively targets pathological angiogenesis and lymphangiogenesis. J Exp Med 206: $1089-1102$.

Kumasaka T, Seyama K, Mitani K, Sato T, Souma S, Kondo T, Hayashi S, Minami M, Uekusa T, Fukuchi Y, et al. 2004 Lymphangiogenesis in lymphangioleiomyomatosis: Its implication in the progression of lymphangioleiomyomatosis. Am I Surg Pathol 28: 1007-1016.

Kumasaka T, Seyama K, Mitani K, Souma S, Kashiwagi S, Hebisawa A, Sato $T$, Kubo $H$, Gomi $K$, Shibuya $K$, et al 2005. Lymphangiogenesis-mediated shedding of LAM cell clusters as a mechanism for dissemination in lymphangioleiomyomatosis. Am J Surg Pathol 29: 1356-1366.

Kunstfeld R, Hirakawa S, Hong YK, Schacht V, Lange-Asschenfeldt B, Velasco P, Lin C, Fiebiger E, Wei X, Wu Y, et al. 2004 Induction of cutaneous delayed-type hypersensitivity reactions in VEGF-A transgenic mice results in chronic skin inflammation associated with persistent lymphatic hyperplasia. Blood 104: 1048-1057.

Kyzas PA, Geleff S, Batistatou A, Agnantis NJ, Stefanou D. 2005. Evidence for lymphangiogenesis and its prognostic implica- tions in head and neck squamous cell carcinoma. I Pathol 206: $170-177$.

Lahat G, Lazar A, Wang X, Wang WL, Zhu QS, Hunt KK, Pollock $\mathrm{RE}, \mathrm{Lev} \mathrm{D}$. 2009. Increased vascular endothelial growth factor$\mathrm{C}$ expression is insufficient to induce lymphatic metastasis in human soft-tissue sarcomas. Clin Cancer Res 15: 2637-2646.

Leak LV, Burke JF. 1966. Fine structure of the lymphatic capillary and the adjoining connective tissue area. Am I Anat 118: 785-809.

Lim HY, Rutkowski JM, Helft J, Reddy ST, Swartz MA, Randolph GJ, Angeli V. 2009. Hypercholesterolemic mice exhibit lymphatic vessel dysfunction and degeneration. $A m$ J Pathol 175: 1328-1337.

Lin J, Lalani AS, Harding TC, Gonzalez M, Wu WW, Luan B, Tu GH, Koprivnikar K, VanRoey MJ, He Y, et al. 2005. Inhibition of lymphogenous metastasis using adeno-associated virusmediated gene transfer of a soluble VEGFR-3 decoy receptor. Cancer Res 65: 6901-6909.

Ma GC, Liu CS, Chang SP, Yeh KT, Ke YY, Chen TH, Wang BB, Kuo SI, Shih JC, Chen M. 2008. A recurrent ITGA9 missense mutation in human fetuses with severe chylothorax: Possible correlation with poor response to fetal therapy. Prenat Diagn 28: 1057-1063.

Machnik A, Neuhofer W, Jantsch J, Dahlmann A, Tammela T, Machura K, Park JK, Beck FX, Muller DN, Derer W, et al. 2009. Macrophages regulate salt-dependent volume and blood pressure by a vascular endothelial growth factorC-dependent buffering mechanism. Nat Med 15: 545-552.

Mandriota SJ, Jussila L, Jeltsch M, Compagni A, Baetens D, Prevo R, Banerji S, Huarte J, Montesano R, Jackson DG, et al. 2001. Vascular endothelial growth factor-C-mediated lymphangiogenesis promotes tumour metastasis. EMBO I 20: 672682.

Martinez de la Torre Y, Locati M, Buracchi C, Dupor J, Cook DN, Bonecchi R, Nebuloni M, Rukavina D, Vago L, Vecchi A, et al. 2005. Increased inflammation in mice deficient for the chemokine decoy receptor D6. Eur I Immunol 35: 13421346.

Maruyama K, Ii M, Cursiefen C, Jackson DG, Keino H, Tomita M, Van Rooijen N, Takenaka H, D'Amore PA, Stein-Streilein $\mathrm{J}$, et al. 2005. Inflammation-induced lymphangiogenesis in the cornea arises from CD11b-positive macrophages. J Clin Invest 115: 2363-2372.

Mattacks CA, Sadler D, Pond CM. 2003. The cellular structure and lipid/protein composition of adipose tissue surrounding chronically stimulated lymph nodes in rats. I Anat 202: 551-561.

Meige H. 1898. Dystrophie oedemateuse hereditaire. Presse Med 6: 341-343.

Milroy, W.F. 1892. An undescribed variety of hereditary oedema. NY Med J 56: 505-508.

Muller A, Homey B, Soto H, Ge N, Catron D, Buchanan ME, McClanahan T, Murphy E, Yuan W, Wagner SN, et al. 2001. Involvement of chemokine receptors in breast cancer metastasis. Nature 410: $50-56$.

Neel JV, Schull WJ. 1954. Human heredity, pp. 50-51. University of Chicago Press, Chicago, IL.

Nibbs RJ, Kriehuber E, Ponath PD, Parent D, Qin S, Campbell JD, Henderson A, Kerjaschki D, Maurer D, Graham GJ, et al. 2001. The $\beta$-chemokine receptor D6 is expressed by lymphatic endothelium and a subset of vascular tumors. Am J Pathol 158: 867-877.

Nougues J, Reyne Y, Dulor JP. 1988. Differentiation of rabbit adipocyte precursors in primary culture. Int J Obes 12: 321333.

Oka M, Iwata C, Suzuki HI, Kiyono K, Morishita Y, Watabe T, Komuro A, Kano MR, Miyazono K. 2008. Inhibition of 
endogenous TGF- $\beta$ signaling enhances lymphangiogenesis. Blood 111: 4571-4579.

Oliver G. 2004. Lymphatic vasculature development. Nat Rev Immunol 4: 35-45.

Oliver G, Alitalo K. 2005. The lymphatic vasculature: Recent progress and paradigms. Annu Rev Cell Dev Biol 21: 457-483.

Oliver G, Detmar M. 2002. The rediscovery of the lymphatic system: Old and new insights into the development and biological function of the lymphatic vasculature. Genes Dev 16: 773-783.

Oliver G, Srinivasan RS. 2008. Lymphatic vasculature development: Current concepts. Ann N Y Acad Sci 1131: 75-81.

Padera TP, Kadambi A, di Tomaso E, Carreira CM, Brown EB, Boucher Y, Choi NC, Mathisen D, Wain J, Mark EJ, et al. 2002. Lymphatic metastasis in the absence of functional intratumor lymphatics. Science 296: 1883-1886.

Pennisi D, Gardner J, Chambers D, Hosking B, Peters J, Muscat G, Abbott C, Koopman P. 2000. Mutations in Sox18 underlie cardiovascular and hair follicle defects in ragged mice. Nat Genet 24: 434-437.

Petrova TV, Makinen T, Makela TP, Saarela J, Virtanen I, Ferrell RE, Finegold DN, Kerjaschki D, Yla-Herttuala S, Alitalo K. 2002. Lymphatic endothelial reprogramming of vascular endothelial cells by the Prox-1 homeobox transcription factor. EMBO I 21: 4593-4599.

Petrova TV, Karpanen T, Norrmen C, Mellor R, Tamakoshi T, Finegold D, Ferrell R, Kerjaschki D, Mortimer P, Yla-Herttuala S, et al. 2004. Defective valves and abnormal mural cell recruitment underlie lymphatic vascular failure in lymphedema distichiasis. Nat Med 10: 974-981.

Pfarr KM, Debrah AY, Specht S, Hoerauf A. 2009. Filariasis and lymphoedema. Parasite Immunol 31: 664-672.

Podgrabinska S, Kamalu O, Mayer L, Shimaoka M, Snoeck H, Randolph GJ, Skobe M. 2009. Inflamed lymphatic endothelium suppresses dendritic cell maturation and function via Mac-1/ ICAM-1-dependent mechanism. J Immunol 183: 1767-1779.

Pond CM. 2003. Paracrine interactions of mammalian adipose tissue. I Exp Zoolog A Comp Exp Biol 295: 99-110.

Pond CM, Mattacks CA. 1995. Interactions between adipose tissue around lymph nodes and lymphoid cells in vitro. I Lipid Res 36: 2219-2231.

Pond CM, Mattacks CA. 2003. The source of fatty acids incorporated into proliferating lymphoid cells in immunestimulated lymph nodes. Br J Nutr 89: 375-383.

Risau W, Flamme I. 1995. Vasculogenesis. Annu Rev Cell Dev Biol 11: 73-91.

Roberts N, Kloos B, Cassella M, Podgrabinska S, Persaud K, Wu Y, Pytowski B, Skobe M. 2006. Inhibition of VEGFR-3 activation with the antagonistic antibody more potently suppresses lymph node and distant metastases than inactivation of VEGFR-2. Cancer Res 66: 2650-2657.

Rockson SG. 2001. Lymphedema. Am J Med 110: 288-295.

Rudkin GH, Miller TA. 1994. Lipedema: A clinical entity distinct from lymphedema. Plast Reconstr Surg 94: 841-847.

Saaristo A, Tammela T, Timonen J, Yla-Herttuala S, Tukiainen E, Asko-Seljavaara S, Alitalo K. 2004. Vascular endothelial growth factor-C gene therapy restores lymphatic flow across incision wounds. FASEB J 18: 1707-1709.

Saban MR, Memet S, Jackson DG, Ash J, Roig AA, Israel A, Saban R. 2004. Visualization of lymphatic vessels through NF-кB activity. Blood 104: 3228-3230.

Sabin F. 1902. On the origin of the lymphatics system from the veins and the development of the lymph hearts and the thoracic duct in the pig. Am I Anat 1: 367-389.

Schoppmann SF, Birner P, Stockl J, Kalt R, Ullrich R, Caucig C, Kriehuber E, Nagy K, Alitalo K, Kerjaschki D. 2002. Tumor- associated macrophages express lymphatic endothelial growth factors and are related to peritumoral lymphangiogenesis. Am J Pathol 161: 947-956.

Seyama K, Kumasaka T, Souma S, Sato T, Kurihara M, Mitani K, Tominaga S, Fukuchi Y. 2006. Vascular endothelial growth factor-D is increased in serum of patients with lymphangioleiomyomatosis. Lymphat Res Biol 4: 143152.

Shibata MA, Morimoto J, Shibata E, Otsuki Y. 2008. Combination therapy with short interfering RNA vectors against VEGF-C and VEGF-A suppresses lymph node and lung metastasis in a mouse immunocompetent mammary cancer model. Cancer Gene Ther 15: 776-786.

Skobe M, Brown LF, Tognazzi K, Ganju RK, Dezube BJ, Alitalo K, Detmar M. 1999. Vascular endothelial growth factor-C (VEGF-C) and its receptors KDR and flt-4 are expressed in AIDS-associated Kaposi's sarcoma. I Invest Dermatol 113: 1047-1053.

Skobe M, Hawighorst T, Jackson DG, Prevo R, Janes L, Velasco P, Riccardi L, Alitalo K, Claffey K, Detmar M. 2001. Induction of tumor lymphangiogenesis by VEGF-C promotes breast cancer metastasis. Nat Med 7: 192-198.

Srinivasan RS, Dillard ME, Lagutin OV, Lin FJ, Tsai S, Tsai MJ, Samokhvalov IM, Oliver G. 2007. Lineage tracing demonstrates the venous origin of the mammalian lymphatic vasculature. Genes Dev 21: 2422-2432.

Stacker SA, Caesar C, Baldwin ME, Thornton GE, Williams RA, Prevo R, Jackson DG, Nishikawa S, Kubo H, Achen MG. 2001. VEGF-D promotes the metastatic spread of tumor cells via the lymphatics. Nat Med 7: 186-191.

Stolk WA, de Vlas SJ, Habbema JD. 2005. Anti-Wolbachia treatment for lymphatic filariasis. Lancet 365: 2067-2068.

Suga H, Araki J, Aoi N, Kato H, Higashino T, Yoshimura K. 2009. Adipose tissue remodeling in lipedema: Adipocyte death and concurrent regeneration. I Cutan Pathol 36: 1293-1298.

Sugiura T, Inoue Y, Matsuki R, Ishii K, Takahashi M, Abe M, Shirasuna K. 2009. VEGF-C and VEGF-D expression is correlated with lymphatic vessel density and lymph node metastasis in oral squamous cell carcinoma: Implications for use as a prognostic marker. Int J Oncol 34: 673-680.

Szuba A, Skobe M, Karkkainen MJ, Shin WS, Beynet DP, Rockson NB, Dakhil N, Spilman S, Goris ML, Strauss HW, et al. 2002. Therapeutic lymphangiogenesis with human recombinant VEGF-C. FASEB J 16: 1985-1987.

Tammela T, Alitalo K. 2010. Lymphangiogenesis: Molecular mechanisms and future promise. Cell 140: 460-476.

Tammela T, Saaristo A, Holopainen T, Lyytikka J, Kotronen A, Pitkonen M, Abo-Ramadan U, Yla-Herttuala S, Petrova TV, Alitalo K. 2007. Therapeutic differentiation and maturation of lymphatic vessels after lymph node dissection and transplantation. Nat Med 13: 1458-1466.

Tobler NE, Detmar M. 2006. Tumor and lymph node lymphangiogenesis-Impact on cancer metastasis. I Leukoc Biol 80: 691-696.

Van Balkom ID, Alders M, Allanson J, Bellini C, Frank U, De Jong G, Kolbe I, Lacombe D, Rockson S, Rowe P, et al. 2002. Lymphedema-lymphangiectasia-mental retardation (Hennekam) syndrome: A review. Am J Med Genet 112: 412-421.

Van den Eynden GG, Vandenberghe MK, van Dam PJ, Colpaert CG, van Dam P, Dirix LY, Vermeulen PB, Van Marck EA. 2007. Increased sentinel lymph node lymphangiogenesis is associated with nonsentinel axillary lymph node involvement in breast cancer patients with a positive sentinel node. Clin Cancer Res 13: 5391-5397. 
Vignes S, Arrault M, Bonhomme S, Spielmann M. 2007. [Upper limb lymphedema revealing breast cancer]. Rev Med Interne 28: 631-634.

Wang HW, Trotter MW, Lagos D, Bourboulia D, Henderson S, Makinen T, Elliman S, Flanagan AM, Alitalo K, Boshoff C. 2004. Kaposi sarcoma herpesvirus-induced cellular reprogramming contributes to the lymphatic endothelial gene expression in Kaposi sarcoma. Nat Genet 36: 687-693.

Wang L, Zhu J, Shan S, Qin Y, Kong Y, Liu J, Wang Y, Xie Y. 2008. Repression of interferon- $\gamma$ expression in $\mathrm{T}$ cells by Prospero-related homeobox protein. Cell Res 18: 911-920.

Weisberg SP, McCann D, Desai M, Rosenbaum M, Leibel RL, Ferrante AW Jr. 2003. Obesity is associated with macrophage accumulation in adipose tissue. I Clin Invest 112: 17961808.

Wigle JT, Oliver G. 1999. Prox1 function is required for the development of the murine lymphatic system. Cell 98: 769778.

Wigle JT, Harvey N, Detmar M, Lagutina I, Grosveld G, Gunn MD, Jackson DG, Oliver G. 2002. An essential role for Prox1 in the induction of the lymphatic endothelial cell phenotype. EMBO I 21: 1505-1513.

Wiley HE, Gonzalez EB, Maki W, Wu MT, Hwang ST. 2001. Expression of CC chemokine receptor-7 and regional lymph node metastasis of B16 murine melanoma. J Natl Cancer Inst 93: $1638-1643$.

Witte MH, Bernas MJ, Martin CP, Witte CL. 2001. Lymphangiogenesis and lymphangiodysplasia: From molecular to clinical lymphology. Microsc Res Tech 55: 122-145.

Wong SY, Haack H, Crowley D, Barry M, Bronson RT, Hynes RO. 2005. Tumor-secreted vascular endothelial growth factor-C is necessary for prostate cancer lymphangiogenesis, but lymphangiogenesis is unnecessary for lymph node metastasis. Cancer Res 65: 9789-9798.

Wynd S, Melrose WD, Durrheim DN, Carron J, Gyapong M. 2007. Understanding the community impact of lymphatic filariasis: A review of the sociocultural literature. Bull World Health Organ 85: 493-498.

Xu H, Barnes GT, Yang Q, Tan G, Yang D, Chou CJ, Sole J, Nichols A, Ross JS, Tartaglia LA, et al. 2003. Chronic inflammation in fat plays a crucial role in the development of obesity-related insulin resistance. J Clin Invest 112: 18211830.

Yoon YS, Murayama T, Gravereaux E, Tkebuchava T, Silver M, Curry C, Wecker A, Kirchmair R, Hu CS, Kearney M, et al. 2003. VEGF-C gene therapy augments postnatal lymphangiogenesis and ameliorates secondary lymphedema. J Clin Invest 111: 717-725.

Zinn AR, Tonk VS, Chen Z, Flejter WL, Gardner HA, Guerra R, Kushner H, Schwartz S, Sybert VP, Van Dyke DL, et al. 1998. Evidence for a Turner syndrome locus or loci at Xp11.2p22.1. Am J Hum Genet 63: 1757-1766. 


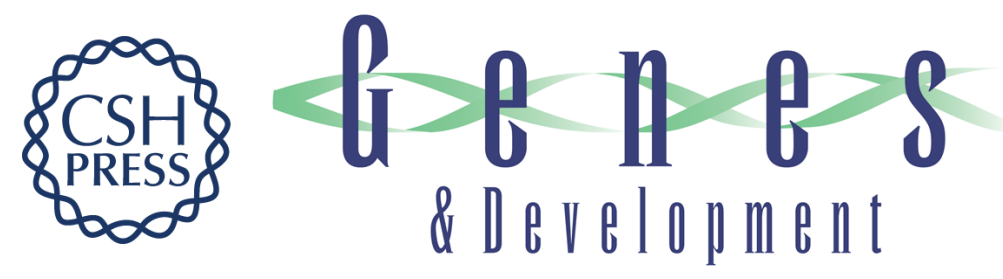

\section{Current views on the function of the lymphatic vasculature in health and disease}

Yingdi Wang and Guillermo Oliver

Genes Dev. 2010, 24:

Access the most recent version at doi:10.1101/gad.1955910

References This article cites 141 articles, 34 of which can be accessed free at: http://genesdev.cshlp.org/content/24/19/2115.full.html\#ref-list-1

License

Email Alerting

Receive free email alerts when new articles cite this article - sign up in the box at the top Service right corner of the article or click here.

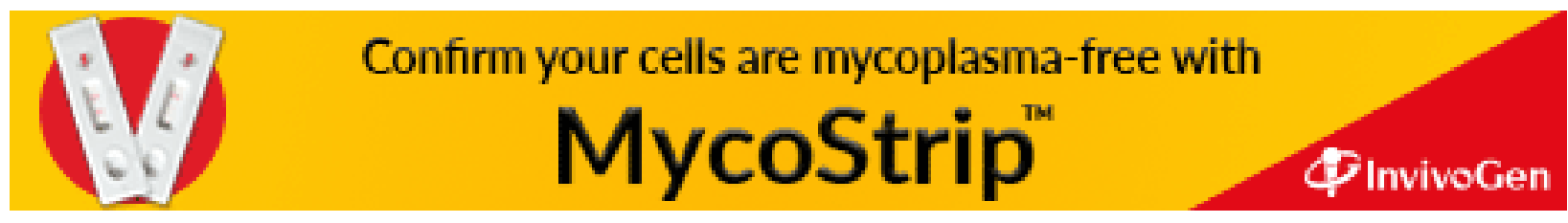

